Ks. LUCJAN ŚWITO

Wydział Teologii

Uniwersytetu Warmińsko-Mazurskiego w Olsztynie

MAŁGORZATA TOMKIEWICZ

Wydział Teologii

Uniwersytetu Warmińsko-Mazurskiego w Olsztynie

\title{
KARNOPRAWNY OBOWIĄZEK DENUNCJACJI (ART. 240 K.K.) A TAJEMNICA POSŁUGI RELIGIJNEJ
}

Treść: Wstęp. - 1. Pomiędzy obowiązkiem zawodowej dyskrecji a denuncjacją - poglądy doktryny. - 2. Tajemnica posługi religijnej. - 3. Wnioski i postulaty de lege ferenda.

\section{Wstęp}

Dokonana ustawą z dnia 23 marca 2017 r. ${ }^{1}$ nowelizacja art. 240 Kodeksu karnego ${ }^{2}$ w znaczący sposób rozszerzyła zakres przedmiotowy zawartego w tym przepisie obowiązku denuncjacji. Oprócz najpoważniejszych przestępstw przeciwko pokojowi, ludzkości oraz przestępstw wojennych, a także przestępstw przeciwko życiu i zdrowiu oraz bezpieczeństwu powszechnemu i wolności (art. 118, art. 118a, art. 120-124, art. 127, art. 128, art.130, art. 134, art. 140, art. 148,

\footnotetext{
${ }^{1}$ Ustawa z dnia 23 marca 2017 r. o zmianie ustawy - Kodeks karny, ustawy o postępowaniu w sprawach nieletnich oraz ustawy - Kodeks postępowania karnego (Dz.U. z 2017 r. poz. 773). Zmiana w zakresie nowelizacji art. 240 k.k. weszła w życie $\mathrm{z}$ dniem 13 lipca $2017 \mathrm{r}$.

${ }^{2}$ Ustawa z dnia 6 czerwca 1997 r. - Kodeks karny, Dz.U. 1997, nr 88, poz. 553 (dalej jako k.k.).
} 
art. 156, art. 163, art. 166, art. 189, art. 252 k.k.), wprowadzono również przestępstwa o charakterze terrorystycznym a także przeciwko wolności seksualnej i obyczajności. W tej ostatniej grupie czynów obowiązkiem denuncjacji objęto zgwałcenie (wspólnie z inną osobą, wobec małoletniego poniżej lat 15 , wobec wstępnego, zstępnego, przysposobionego, przysposabiającego, brata lub siostry a także zgwałcenie ze szczególnym okrucieństwem - art. 197 \$ 3 i 4 k.k.), jak również seksualne wykorzystanie niepoczytalności lub bezbronności (art. 198 k.k.) oraz pedofilię i prezentowanie małoletniemu treści pornograficznych (art. 200 k.k.).

Zgodnie z obecnym brzmieniem wymienionego art. $240 \$ 1$ k.k., każdy, kto mając wiarygodną ${ }^{3}$ wiadomość o karalnym przygotowaniu ${ }^{4}$ albo usiłowaniu lub dokonaniu czynu zabronionego ${ }^{5}$, określonego we wszystkich wymienionych przepisach, nie zawiadomi ${ }^{6}$

\footnotetext{
${ }^{3}$ Musi to być informacja zasługująca na zaufanie, pewna, jednakże nie chodzi tu o stuprocentową pewność co do faktu zaistnienia czynu zabronionego, a jedynie wystąpienie wysokiego stopnia prawdopodobieństwa, iż czyn taki miał miejsce (M. Mozgawa, Komentarz aktualizowany do art. 240 Kodeksu karnego, w: Kodeks karny. Komentarz aktualizowany, red. M. Mozgawa, LEX/el, 2017, teza 5). Dana osoba nie ma obowiązku sprawdzania faktów, jak również nie ponosi odpowiedzialności w przypadku, gdy okaże się, że przestępstwo nie zostało popełnione, choć okoliczności na to wskazywały (A. MAREK, Kodeks karny. Komentarz, Warszawa 2010, s. 526-527).

${ }^{4}$ Przygotowanie jest karalne w przypadku przestępstwa $\mathrm{z}$ art. $118 \$ 1$ i 2 (na mocy art. $126 \mathrm{c} \$ 1)$, art. 118 a (art. $126 \mathrm{c} \$ 2)$, art. $127 \$ 1$ (art. $127 \$ 2)$, art. $128 \$ 1$ (art. 128 $\S 2)$, art. $140 \$ 1$ (art. $140 \$ 3)$, art. $163 \$ 1$ (art. 168), art. $166 \$ 1$ (art. 168), art. $252 \$ 1$ (art. $252 \$ 3$ ). W pozostałych przypadkach przygotowanie nie jest karalne.

${ }^{5}$ Obecna treść art. 240 literalnie wskazuje, że obowiązek odnosi się do „czynu zabronionego”, a nie do „przestępstwa”, co oznacza to, że ów obowiązek potencjalnie odnosi się również do takich sytuacji, w których sprawca czynu objętego zawiadomieniem faktycznie realizuje znamiona typu czynu zabronionego, lecz nie może ponosić odpowiedzialności karnej, np. z uwagi na wiek czy niepoczytalność (zob. M. Szewczy K, A. Wojtaszy , W. Zontek, Komentarz do art. 240 Kodeksu karnego, LEX/el 2017, teza 7).

${ }^{6}$ Zawiadomienie może być złożone do jakiegokolwiek organu powołanego do ścigania przestępstw (Policja, prokuratura, Agencja Bezpieczeństwa Wewnętrznego, Służba Celna, CBA, Żandarmeria Wojskowa oraz inne organy przewidziane
} 
niezwłocznie ${ }^{7}$ organu powołanego do ścigania przestępstw podlega karze pozbawienia wolności do lat 3. Nie popełnia przestępstwa określonego w $\$ 1$, kto zaniechał zawiadomienia, mając dostateczną podstawę do przypuszczenia, że wymieniony w $\$ 1$ organ wie o przygotowywanym, usiłowanym lub dokonanym czynie zabronionym; nie popełnia przestępstwa również ten, kto zapobiegł popełnieniu przygotowywanego lub usiłowanego czynu zabronionego określonego $\mathrm{w} \$ 1$ (art. $240 \$ 2$ k.k.).

Nie podlega karze pokrzywdzony czynem wymienionym w $\$ 1$, który zaniechał zawiadomienia o tym czynie (art. $240 \$ 2 \mathrm{a}$ k.k.), jak również nie podlega karze ten, kto zaniechał zawiadomienia z obawy przed odpowiedzialnością karną grożącą jemu samemu lub jego najbliższym (art. $240 \$ 3$ k.k.).

Zastąpienie dotychczasowego obowiązku społecznego (art. 304 k.p.k.) karnoprawnym obowiązkiem denucjacji w odniesieniu do przestępstw dotyczących sfery seksualnej uzasadniano potrzebą zwiększenia ochrony ofiar tego rodzaju przestępstw, w tym głównie wzmocnienia poziomu ochrony małoletnich i osób nieporadnych ze względu na swój stan psychiczny i fizyczny. Uznając powyższy cel nowelizacji za potrzebny i społecznie doniosły nie sposób jednak nie zadać pytania, o relację obowiązku wynikającego $\mathrm{z}$ analizowanej normy prawnej, do konstytucyjnie chronionej wolności sumienia

w przepisach szczególnych - por. art. 311 i 312 k.p.k.) i nie wymaga ono zachowania jakiejś szczególnej formy (może być ustne, pisemne, telefoniczne, przez e-mail czy nawet SMS). Nie jest konieczne, aby adresatem zawiadomienia był dokładnie ten właśnie organ, który przedmiotowo zajmuje się daną problematyką (M. MozGAWA, dz. cyt., teza 6).

${ }^{7}$ Niezwłocznie czyli w jak najkrótszym czasie, po którym dana osoba dowiedziała się z wiarygodnego źródła o fakcie zaistnienia czynu zabronionego. Wyznaczenie szczegółowego zakresu temporalnego określenia „niezwłocznie” uzależnione jest od sytuacji, w jakiej znajdowała się dana osoba (K. WIAK, Komentarz do art. 240 k.k., w: Kodeks karny. Komentarz, red. A. Grześkowiak, K. Wiak, Warszawa 2017, s. 1123). 
i wyznania (religii) oraz prawa do prywatności, w tym prawa do dyskrecji związanego z życiem duchowym i praktykami religijnymi ${ }^{8}$.

Czy obowiązek zawiadomienia organów ścigania dotyczy zatem osób duchownych i zakonnych, którzy tego rodzaju informacje pozyskali w trakcie posługi religijnej? Czy powstaje on nawet wówczas, gdy w trakcie rozmowy duchowej osoba pokrzywdzona wyraźnie oświadczy, że nie chce informowania policji oraz prokuratury i gdy w uzasadniony sposób można przypuszczać, że ewentualne zawiadomienie i jego procesowe konsekwencje mogą odbić się negatywnie na psychice ofiary? Artykuł stanowi próbę odpowiedzi na te pytania.

\section{Pomiędzy obowiązkiem zawodowej dyskrecji a denuncjacją - poglądy doktryny}

„Tajemnica” w rozumieniu potocznym oznacza pewien sekret, charakteryzujący się tajnością i tym, że nie powinien wyjść na jaw ${ }^{9}$; to wiadomość (sprawa, fakt, wiadomość o fakcie), której nie należy rozgłaszać ${ }^{10}$. Takie rozumienie jest - co do istoty - tożsame $z$ rozumieniem tajemnicy w języku prawniczym, w tym również w odniesieniu

${ }^{8}$ Europejska Konwencja o Ochronie Praw Człowieka i Podstawowych Wolności oraz Międzynarodowy Pakt Praw Obywatelskich i Politycznych nie używają określenia „praktyki religijne”, posługując się imiesłowem „praktykowanie”. Wymienione akty terminu tego nie definiują, aczkolwiek określenie to pojmowane jest w ten sposób, że odnosi się do czynności i działań motywowanych religijnie. Z brzmienia art. 53 ust. 2 Konstytucji RP wynika natomiast, że praktykowaniem jest uzewnętrznianie ,indywidualnie lub z innymi, publicznie lub prywatnie, swojej religii”. W literaturze, zwłaszcza związanej z katolicką nauką społeczną, przyjmuje się, iż praktykowanie to uprawianie kultu, modlitwa i uczestniczenie w obrzędach (K. WarchaŁowski, Prawo do wolności myśli sumienia i religii w Europejskiej Konwencji Praw Człowieka i Podstawowych Wolności, Lublin 2004, s. 121). Szerzej na temat zakresu przedmiotowego „praktykowania religii” zob. J. SobCzAK, M. GoŁdA-SobczaK, Wolność sumienia i wyznania jako prawo człowieka, Annales Universitatis Mariae Curie-Skłodowska, Lublin 2012, vol. XIX, nr 1, s. 54-60.

${ }^{9}$ J. WARYLEWsKi, Tajemnica adwokacka i odpowiedzialność karna za jej naruszenie (ujawnienie), Palestra 5-6(2015), s. 7.

${ }^{10}$ J. Soвсzак, Tajemnica lekarska, Medyczna Wokanda, 2016, nr 8, s. 58. 
do tajemnicy zawodowej obowiązującej osoby wykonujące zawody zaufania publicznego ${ }^{11}$.

Zachowanie zawodowej dyskrecji w przypadku zawodów opartych na zaufaniu jest podstawowym mechanizmem ochrony tak fundamentalnych, konstytucyjnie chronionych praw jednostki, jak prawo do prywatności czy swoboda komunikowania się (art. 47 i art. 57 Konstytucji RP), toteż ochrona tajemnicy zawodowej zajmuje silną pozycję w systemie prawa i gwarantowana jest w wielu rozwiązaniach normatywnych ${ }^{12}$. Ochrona ta nie ma jednak charakteru absolutnego. Pomijając dyskusje, jakie w literaturze przedmiotu toczą się wokół pytania, czy ochrona tajemnicy zawodowej ma charakter względny czy bezwzględny, w doktrynie nie ma też jednoznacznej odpowiedzi, jak należy rozstrzygać kolizje zachodzące pomiędzy ochroną tajemnicy zawodowej a interesem wymiaru sprawiedliwości, zwłaszcza w odniesieniu do obowiązku określonego w art. 240 k.k. Poglądy, jakie w kwestii tej pojawiły się na kanwie dotychczasowego brzmienia art. 240 k.k., są zróżnicowane.

Według E. Plebanek i M. Rusinka zawodowa dyskrecja w kolizji z interesami wymiaru sprawiedliwości winna mieć, co do zasady, pierwszeństwo i tylko wyjątkowo możliwe jest poświęcenie jej dla realizacji celów procesu karnego. Zdaniem tych autorów „[....] w braku innych argumentów, w oparciu o tzw. aksjologiczną regułę kolizyjną, kolizję między obowiązkiem zachowania tajemnicy zawodowej

11 Tajemnica zawodowa dotyczy m.in. tajemnicy notarialnej, adwokackiej, radcy prawnego, doradcy podatkowego, lekarskiej, dziennikarskiej, statystycznej, tajemnicy Prokuratorii Generalnej, tajemnicy diagnostyki laboratoryjnej, pielęgniarek i położnych, tajemnicy psychologów, kuratorów sądowych, pomocy społecznej i in. (zob. szerzej M. RusineK, Tajemnica zawodowa i jej ochrona w polskim procesie karnym, Oficyna 2007, s. 44-48).

12 Poza ograniczeniami dowodowymi w procesach, prawodawca statuuje również odpowiedzialność karną za naruszenie tajemnicy zawodowej. Norma art. $266 \$ 1$ k.k. stanowi, że każdy, „kto wbrew przepisom ustawy lub przyjętemu na siebie zobowiązaniu, ujawnia lub wykorzystuje informację, z którą zapoznał się w związku z pełnioną funkcją, wykonywaną pracą, działalnością publiczną, społeczną, gospodarczą lub naukową, podlega grzywnie, karze ograniczenia wolności albo pozbawienia wolności do lat 2". 
a obowiązkiem denuncjacji z art. $240 \$ 1$ k.k. należy rozstrzygać na korzyść tej pierwszej powinności - z całokształtu regulacji procesowej wynika bowiem, że ustawodawca generalnie przyznaje pierwszeństwo zawodowej dyskrecji”'13.

Podobny pogląd, w odniesieniu do tajemnicy obrończej wykonywanej przez radcę prawnego, prezentuje A. Światłowski. Stoi on na stanowisku, iż „bez wątpienia tajemnica obrończa ma [...] prymat nad obowiązkiem denuncjacji”. Autor ten rozważa: „Co jednak, gdy o zabójstwie, czy o planowanym zawładnięciu statkiem powietrznym dowiedział się w okolicznościach chronionych «tylko» tajemnicą radcowską? Należy uznać, że w takim wypadku odpowiedzialność karna radcy jest wyłączona przez pozakodeksowy kontratyp (okoliczność wyłączającą bezprawność) - działanie w ramach szczególnych uprawnień i obowiązków. Uchylając się od denuncjacji przestępstwa wymienionego w art. 240 k.k., o którym dowiedział się w ramach czynności zawodowych (innych niż obrona), radca nie popełnia przestępstwa $\mathrm{z}$ art. $240 \mathrm{k} . \mathrm{k}$. wobec braku bezprawności takiego zachowania, uczynił bowiem to, co nakazywały mu wiążące go przepisy"14.

W ten nurt rozważań wpisuje się również pogląd K. Brocławik i M. Czajki. Autorzy ci w odpowiedzi na pytanie: czy nie powstaje możliwość poniesienia odpowiedzialności karnej z art. 240 k.k., jeżeli radca jest $\mathrm{w}$ posiadaniu informacji, które dotyczą wymienionych w tym przepisie typów czynów zabronionych, a wiedza ta ma charakter zawodowy, stawiają tezę, iż „wątpliwość tę należy rozstrzygnąć na korzyść radców, przyjmując, że prawo nie może karać za zachowanie, które samo nakazuje"15.

Innego zdania natomiast, na przykładzie tajemnicy notarialnej, jest C. Kłak. Autor ten uważa, iż obowiązek zawiadomienia

\footnotetext{
${ }^{13}$ E. Plebanek, M. Rusinek, Ujawnienie tajemnicy zawodowej w procesie karnym a odpowiedzialność karna, Czasopismo Prawa Karnego i Nauk Penalnych, 11(2007), z. 1, s. 73.

${ }^{14}$ A. ŚwiatŁowski, Radca prawny jako obrońca $w$ postępowaniu $w$ sprawach o wykroczenia, Radca Prawny, 2002, nr 2, s. 6.

${ }^{15}$ K. BrocŁawik, M. Czajka, Prawnokarne aspekty ochrony tajemnicy zawodowej radcy prawnego, cz. II. Zagadnienia procesowe, Radca Prawny, 2001, nr 4, s. 42.
} 
o przestępstwie, wynikający z art. $240 \$ 1$ k.k., dotyczy bez żadnych wyjątków każdego. Uchyla on zatem obowiązek zachowania tajemnicy notarialnej, a to z kolei oznacza, że w warunkach określonych w tym przepisie notariusz zobowiązany jest zawiadomić o przestępstwie. Autor pisze, iż „Ustawodawca, decydując się na objęcie określonych okoliczności tajemnicą zawodową, władny jest [...] wprowadzić odstępstwa od obowiązku zachowania tajemnicy, które zawsze muszą być uzasadnione. Biorąc pod uwagę fakt, że w art. $240 \$ 1$ k.k. wskazano najpoważniejsze przestępstwa przeciwko państwu i jednostce, trudno uznać, że obowiązek ten został zakreślony nieracjonalnie, uniemożliwiając np. wykonywanie zawodu notariusza ze względu na nieuzasadnione naruszenie poufności jego relacji z klientem"16.

Podobne stanowisko, w odniesieniu do tajemnicy lekarskiej, prezentuje A. Augustynowicz i I. Wrześniewska-Wal. Autorki te stoją na stanowisku, że obowiązek zawiadomienia o przestępstwie uchyla tajemnicę lekarską: „Lekarz, który w związku z wykonywaniem swojego zawodu uzyskał wiarygodną informację o przygotowaniu, usiłowaniu lub dokonaniu czynów zabronionych wymienionych w art. $240 \$ 1$ k.k., ma obowiązek niezwłocznego powiadomienia organów ścigania"17.

Z kolei zdaniem M. Szewczyk, A. Wojtaszczyka i W. Zontka, formułujących swoje poglądy w oparciu już o aktualne brzmienie art. 240 k.k., „obowiązek denuncjacji opisany w art. 240 k.k. nie stanowi samoistnej przesłanki uchylenia ustawowego obowiązku zachowania określonej tajemnicy. Tak opisany obowiązek denuncjacji ma bowiem charakter powszechny, natomiast regulacje odnoszące się do obowiązku zachowania tajemnicy nie mają charakteru powszechnego, lecz zawsze są adresowane do określonej kategorii podmiotów. W takiej perspektywie art. 240 stanowi więc przepis ogólny w stosunku

${ }^{16}$ Cz. KŁAK, Notariusz i samorząd notarialny a obowiązek zawiadomienia o przestępstwie, Nowy Przegląd Notarialny, 2013, nr 1, s. 39.

17 A. Augustynowicz, I. Wrześniewska-Wal, Zawiadomienie przez lekarza o popetnieniu przestępstwa przeciwko wolności seksualnej i obyczajności a obowiązek zachowania tajemnicy zawodowej, Prawo i Medycyna, 15(2013), nr 3-4, s. 107. 
do regulacji dotyczących obowiązku zachowania tajemnicy, które w takim kontekście mają status przepisów szczególnych"18.

\section{Tajemnica posługi religijnej}

Termin „posługa religijna” jest terminem ustawowym, który występuje w kilkudziesięciu aktach prawnych prawa polskiego ${ }^{19}$, aczkolwiek termin ten, podobnie jak i „tajemnica posługi religijnej”, nie jest ustawowo zdefiniowany. Tajemnicę posługi religijnej prawodawca polski „rozpoznaje” i reguluje expressis verbis w odniesieniu do sakramentu spowiedzi ${ }^{20}$. Ochrona tajemnicy spowiedzi występuje w prawie polskim we wszystkich trzech, zasadniczych porządkach normatywnych, tj. w procedurze karnej, cywilnej i administracyjnej.

$\mathrm{W}$ postępowaniu karnym tajemnica spowiedzi objęta jest zakazem bezwzględnym. Zgodnie z art. 178 pkt. 2 k.p.k. ${ }^{21}$ nie wolno przesłuchi-

\footnotetext{
${ }^{18}$ M. Szewczy K, A. Wojtaszczy K, W. Zontek, dz. cyt., teza 15.

${ }^{19}$ Np. art. 106 ustawy z dnia 6 czerwca 1997 r. - Kodeks karny wykonawczy, Dz.U. 1997, nr 90, poz. 557; Rozporządzenie Ministra Sprawiedliwości w sprawie szczegółowych zasad wykonywania praktyk religijnych i korzystania z posług religijnych w zakładach karnych i aresztach śledczych, Dz.U. 2003, nr 159, poz.1546; art. 31 ustawy z dnia 17 maja 1989 r. o stosunku Państwa do Kościoła katolickiego w RP, Dz.U. 1989, nr 29, poz. 154; art. 16 ustawy z dnia 20 lutego 1997 r. o stosunku Państwa do gmin wyznaniowych żydowskich w RP, Dz.U. 1997, nr 41, poz. 251; art. 19 ustawy z dnia 30 czerwca 1995 r. o stosunku Państwa do Kościoła Chrześcijan Baptystów w RP, Dz.U. 1995, nr 97, poz. 480; art. 27 ustawy z dnia 4 lipca 1991 r. o stosunku Państwa do Polskiego Autokefalicznego Kościoła Prawosławnego, Dz.U. 1991, nr 66, poz. 287 i analogicznie u Adwentystów, Zielonoświątkowców, Mariawitów; art. 45 ustawy z dnia 20 listopada 1998 r. o zryczałtowanym podatku dochodowym od niektórych przychodów osiąganych przez osoby fizyczne, Dz.U. 2016, nr 144, poz. 930; art. 415 ustawy z dnia 12 grudnia 2013 r. o cudzoziemcach, Dz.U. 2013, poz. 1650; art. 66a ustawy z dnia 26 października 1982 r. o postępowaniu w sprawach nieletnich, Dz.U. 1982, nr 35, poz. 1654; art. 19 ustawy z dnia 17 maja 1989 r. o gwarancjach wolności sumienia i wyznania (Dz.U. 1989, nr 29, poz. 155); i wiele innych.

${ }^{20}$ Szerzej zob. M. Tомкiewicz, Tajemnica spowiedzi i tajemnica duszpasterska $w$ procesie karnym, Prokuratura i Prawo 2(2012), s. 50-63 i literatura tam przywołana.

${ }^{21}$ Ustawa z dnia 6 czerwca 1997 r. - Kodeks postępowania karnego, Dz.U. 1997, nr 89, poz. 555 (dalej jako k.p.k.).
} 
wać jako świadków duchownego co do faktów, o których dowiedział się przy spowiedzi.

W procedurze cywilnej tajemnica spowiedzi ma charakter względny. Zgodnie z art. $261 \$ 2$ k.p.c. ${ }^{22}$ świadek może odmówić odpowiedzi na zadane mu pytanie, jeżeli zeznanie mogłoby narazić jego lub jego bliskich, wymienionych w paragrafie poprzedzającym, na odpowiedzialność karną, hańbę lub dotkliwą i bezpośrednią szkodę majątkową albo jeżeli zeznanie miałoby być połączone z pogwałceniem istotnej tajemnicy zawodowej. Duchowny może odmówić zeznań co do faktów powierzonych mu na spowiedzi. W tym przypadku osoba duchowna obowiązana jest stawić się na wezwanie sądu, a sąd każdorazowo poddaje własnej ocenie przesłanki uzasadniające skorzystanie z prawa do odmowy zeznań.

Inaczej sytuacja przedstawia się w postępowaniu administracyjnym. Norma art. $83 \$ 1$ k.p.a. ${ }^{23}$ stanowi, iż nikt nie ma prawa odmówić zeznań w charakterze świadka, z wyjątkiem małżonka strony, wstępnych, zstępnych i rodzeństwa strony oraz jej powinowatych pierwszego stopnia, jak również osób pozostających ze stroną w stosunku przysposobienia, opieki lub kurateli. Prawo odmowy zeznań trwa także po ustaniu małżeństwa, przysposobienia, opieki lub kurateli. Zgodnie natomiast $\mathrm{z} \$ 2$ tego przepisu, świadek może odmówić odpowiedzi na pytania, gdy odpowiedź mogłaby narazić jego lub jego bliskich wymienionych w $\$ 1$ na odpowiedzialność karną, hańbę lub bezpośrednią szkodę majątkową albo spowodować naruszenie obowiązku zachowania prawnie chronionej tajemnicy zawodowej.

Z powyższego wynika zatem, iż organ administracyjny nie może zwolnić osoby związanej tajemnicą zawodową z obowiązku zachowania tej tajemnicy. Może natomiast przesłuchać taką osobę na okoliczności objęte tą tajemnicą, jeżeli osoba ta nie zasłania się tajemnicą

\footnotetext{
${ }^{22}$ Ustawa z dnia 17 listopada 1964 r. - Kodeks postępowania cywilnego, Dz.U. 1964, nr 43, poz. 296 (dalej jako k.p.c.).

${ }^{23}$ Ustawa z dnia 14 czerwca 1960 r. - Kodeks postępowania administracyjnego, Dz.U. 1960, nr 30, poz. 168 (dalej jako k.p.a.).
} 
i zeznania chce złożyćc ${ }^{24}$. Organ prowadzący postępowanie nie ma prawnych możliwości wskazania zasadności lub niezasadności odmowy odpowiedzi na pytanie. Świadek odmawiający odpowiedzi na pytanie obowiązany jest podać podstawę prawną korzystania $\mathrm{z}$ tego prawa, nie podając uzasadnienia przesłanek istnienia tego prawa ${ }^{25}$.

Poza wskazanymi procedurami tajemnica spowiedzi chroniona jest również w przepisach pozakodeksowych ${ }^{26}$.

Wielość regulacji chroniących tajemnicę spowiedzi może prowadzić do wniosku, że tajemnica posługi religijnej w Polsce jest chroniona w stopniu należytym. Problem jednak w tym, że spowiedź nie jest jedyną świadczoną przez osoby duchowne posługą religijną i nie jest też jedyną, praktykowaną przez wierzących formą kontaktów o charakterze duchowym. Niezależnie od spowiedzi, wierni (a także osoby postrzegające siebie jako osoby niezwiązane z żadnym Kościołem czy wspólnotą wyznaniową) mogą wszak okazjonalnie lub stale korzystać z rozmów duszpasterskich i porad duchowych, w których stopień poufności i intymności bywa do spowiedzi zbliżony. Tego

${ }^{24}$ Z. КмІесік, Zakres udostępniania akt sprawy w postępowaniu administracyjnym, Ruch Prawniczy, Ekonomiczny i Socjologiczny 2(2008), s. 95-107.

${ }^{25}$ B. Adamiak, J. Borkowski, Kodeks postępowania administracyjnego. Komentarz, Warszawa, 2011, s. 395.

${ }^{26}$ Zob. np. art. 195 Ustawy z dnia 29 sierpnia 1997 r. Ordynacja podatkowa, Dz.U. 1997, nr 137, poz. 926; art. 43 Ustawy z dnia 23 grudnia 1994 r. o Najwyższej Izbie Kontroli, Dz.U. 1995, nr 13, poz. 59; art. 18 e ust. 4 Ustawy z dnia 19 sierpnia 1994 r. o ochronie zdrowia psychicznego, Dz.U. 1994, nr 111, poz. 535; art. 19 ust. 15 f pkt 1 Ustawy z dnia 6 kwietnia 1990 r. o Policji, Dz.U. 1990, nr 30, poz. 179; art. 16 Ustawy z dnia 12 października 1990 r. o Straży Granicznej, Dz.U. 1990, nr 78, poz. 462; art. 36d ust. f-i Ustawy z dnia 28 września 1991 r. o kontroli skarbowej, Dz.U. 1991, nr 100, poz. 442; art. 31 ust. 16 f-j Ustawy z dnia 24 sierpnia 2001 r. o Żandarmerii Wojskowej i wojskowych organach porządkowych, Dz.U. 2001, nr 123, poz. 1353; art. 27 ust. 15 h-l Ustawa z dnia 24 maja 2002 r. o Agencji Bezpieczeństwa Wewnętrznego oraz Agencji Wywiadu, Dz.U. 2002, nr 74, poz. 676; art. 31 ust. 14 f-j Ustawy z dnia 9 czerwca 2006 r. o Służbie Kontrwywiadu Wojskowego oraz Służbie Wywiadu Wojskowego, Dz.U. 2006, nr 104, poz. 253; art. 17 ust.15 f-j Ustawy z dnia 9 czerwca 2006 r. o Centralnym Biurze Antykorupcyjnym, Dz.U. 2006, nr 104, poz. 708 . 
rodzaju kontakty zajmują szczególne miejsce zwłaszcza w tych Kościołach, które spowiedzi indywidualnej nie przewidują.

Powyższe relacje duchowe objęte są w prawie wewnętrznym Kościołów „tajemnicą duszpasterską” i podlegają wewnętrznej ochronie. Taką ochronę przewiduje wprost np. \$ 105 Pragmatyki Służbowej Kościoła Ewangelicko-Augsburskiego, w którym naruszenie „tajemnicy duszpasterskiej” jest traktowane na równi z naruszeniem „tajemnicy spowiedzi”. W Kościele katolickim tajemnica duszpasterska nie jest wprawdzie regulowana expressis verbis, jednakże wynika z kan. 220 $\mathrm{KPK}^{27} \mathrm{i}$ art. $23 \mathrm{KKKW}^{28}$.

„Tajemnicy duszpasterskiej” nie rozpoznaje jednak prawodawca polski. Tajemnica ta nie jest chroniona w obowiązujących regulacjach prawnych jako tajemnica sui generis, zaś próba traktowania tej tajemnicy w aktualnym stanie prawnym w kategoriach tajemnicy zawodowej, rodzi poważne zastrzeżenia. Przede wszystkim, w literaturze przedmiotu zgłaszane są nie pozbawione racji wątpliwości co do tego, czy w ogóle można mówić o kapłaństwie jako o zawodzie ${ }^{29}$, podobnie jak i wątpliwe jest to, czy w kategoriach zawodu należy rozpatrywać powołanie zakonne. Po wtóre, ustawodawca polski nie sformułował wprawdzie żadnej legalnej definicji tajemnicy zawodowej ${ }^{30}$, jednak

${ }^{27}$ Codex Iuris Canonici. Auctoritate Ioannis Pauli II. promulgatus. Kodeks Prawa Kanonicznego; przekład polski zatwierdzony przez Konferencję Episkopatu Polski, Pallotinum 1984.

${ }^{28}$ Codex Canonum Ecclesiarum Orientalium. Auctoritate Ioannis Pauli PP. II promulgatus, Libreria Editrice Vaticana 1990. Tłumaczenie w jęz. polskim: Kodeks Kanonów Kościołów Wschodnich, Lublin 2002.

${ }^{29}$ Zob. m.in. B. KuniCKA-MichalskA, Ochrona tajemnicy zawodowej w polskim prawie karnym, Warszawa 1972, s. 161-162; Z. CIUPAK, Socjologiczne aspekty „zawodu" kapłana, w: Zawody. Materiały i studia, red. A. Sarapata, Wrocław-Warszawa-Kraków 1964, s. 49 i nast.); L. ŚwiTo, Charakter prawny posługi duszpasterskiej proboszczów i wikariuszy w parafiach rzymskokatolickich w świetle prawa polskiego, Seminare 27(2010), s. 41-50. Sama też definicja tajemnicy zawodowej jest zagadnieniem problematycznym (zob. M. Rusinek, Tajemnica zawodowa..., dz. cyt., s. 62-84).

${ }^{30}$ Według definicji doktrynalnej „tajemnica zawodowa istnieje, gdy wiadomość nią objęta została uzyskana przez osobę reprezentującą określony zawód, z tytułu wykonywania którego było możliwe wejście w posiadanie cudzej tajemnicy czy 
w doktrynie karnistycznej ${ }^{31}$, cywilistycznej ${ }^{32}$, jak i administracyjnej ${ }^{33}$, wypracowanej na gruncie art. 180 k.p.k., art. 261 k.p.c. i art. 83 k.p.a. zdecydowanie przeważa utrwalony od lat pogląd, że omawiany obowiązek zachowania tajemnicy zawodowej wynikać musi z przepisów ustawowych ${ }^{34}$. Ani Kodeks Prawa Kanonicznego Jana Pawła II, ani Pragmatyka Służbowa Kościoła Ewangelicko-Augsburskiego ani też prawo wewnętrzne innych kościołów czy związków wyznaniowych nie przynależy do określonych w art. 87 Konstytucji RP źródeł prawa i nie ma mocy powszechnie obowiązującej na terytorium Rzeczypospolitej Polskiej. Regulacje te mogą wywoływać skutki w polskim porządku prawnym jedynie wówczas, gdy zezwala na to prawo państwowe (aktem rangi ustawowej) i tylko w zakresie tym zezwoleniem objętym. Żaden z obowiązujących przepisów prawa powszechnego nie odsyła w zakresie dotyczącym tajemnicy duszpasterskiej do norm prawa wewnętrznego wspólnot religijnych ani też tego rodzaju norm nie recypuje.

W doktrynie nie brak głosów, że tajemnica zawodowa może wynikać także z samej etyki zawodowej danego zawodu (skodyfikowanej lub nie), ale wobec wskazanych wątpliwości co do tego, czy „ksiądz”, „zakonnik” lub „siostra zakonna” to zawód, rozważanie tej opcji wydaje się być bezprzedmiotowe. Źródłem obowiązku zachowania

sekretu” (M. Budyn-Kulik, P. KozŁowska-Kalisz, M. Kulik, M. Mozgawa, Kodeks karny. Komentarz, Warszawa 2010, s. 489). Podobnie: B. MichalsKA-KunickA, Ochrona..., dz. cyt., s. 12; P. Sow Iński, Prawo świadka do odmowy zeznań w procesie karnym, Warszawa 2004, s. 147.

${ }^{31} \mathrm{~K}$. ŁoJEwski, Instytucja odmowy zeznań w polskim prawie karnym, Warszawa 1970, s. 151; P. Sowiński, Prawo..., s. 166.

${ }^{32}$ Zob. m.in. T. Demendecki, Komentarz do art. 261, w: Kodeks postępowania cywilnego. Komentarz, red. J. Bodio, T. Demendecki, A. Jakubecki, O. Marcewicz, P. Telenga, M. Wójcik, Warszawa 2014, s. 643.

${ }^{33}$ Zob. P. Przyвysz, Kodeks postępowania administracyjnego, Warszawa 2014, s. 198.

${ }^{34}$ Zdarza się jednakże, iż obowiązek zawodowej dyskrecji może mieć swe źródło również w przepisach rozporządzenia, np. $\$ 21$ rozporządzenia Ministra Pracy i Polityki Społecznej z dnia 14 lutego 2005 r. w sprawie placówek opiekuńczo-wychowawczych, Dz.U. 2005, Nr 37, poz. 331. 
dyskrecji może być także umowa cywilno-prawna, ale czy ktokolwiek przed przystąpieniem np. do rozmowy duchowej jakąkolwiek umowę zawiera? W obecnym stanie prawnym nie ma zatem żadnych formalnoprawnych przesłanek, które identyfikowałyby tajemnicę duszpasterską i tajemnicę tę chroniły.

\section{Wnioski i postulaty de lege ferenda}

Odnosząc uwagi powyższe do pytań postawionych we Wstępie stwierdzić należy, iż aktualnie w porządku prawa polskiego nie ma żadnych podstaw, które mogłyby uzasadniać tezę, iż obowiązek określony w art. 240 k.k. nie dotyczy osób duchownych i zakonnych, którzy informacje wskazane $\mathrm{w}$ tym przepisie pozyskali $\mathrm{w}$ trakcie posługi religijnej (za wyjątkiem spowiedzi). Tajemnica duszpasterska nie jest tajemnicą, której obowiązek przestrzegania wynikałby z obowiązujących przepisów prawa świeckiego, w związku z czym tajemnica ta nie jest chroniona w żaden sposób formalnoprawny, w tym nie podlega ochronie, jaka przysługuje tajemnicy zawodowej $^{35}$. Oznacza to, że obowiązek denucjacji powstaje nawet wówczas, gdy w trakcie rozmowy duchowej osoba pokrzywdzona wyraźnie oświadczy, że nie chce, aby w sprawie zostało złożone zawiadomienie o popełnieniu przestępstwa, jak również wówczas, gdy o całkowitą dyskrecję będą apelować rodzice dziecka, którzy sami takiego zawiadomienia nie złożą. Oznacza to również, że każda osoba korzystająca z posługi religijnej musi liczyć się z tym, że okoliczności tej posługi oraz wyjawione w jej trakcie sekrety mogą zostać upublicznione i wykorzystane procesowo a każdy ojciec duchowy lub ksiądz składający wizytę duszpasterską musi liczyć się z tym, że - w zależności od tego co zobaczy lub usłyszy - może być zobligowany prawnie do niezwłocznej denuncjacji.

\footnotetext{
${ }^{35} \mathrm{Na}$ marginesie odnotować należy, iż w odróżnieniu od prawa świeckiego, prawo kanoniczne dostrzega i respektuje również tajemnice zawodowe istniejące w prawie powszechnym. Norma kan. $1548 \$ 2$ pkt 1 KPK wyraźnie stanowi, iż osoby zobowiązane do zachowania tajemnicy urzędowej - w tym m.in. wprost wymienieni urzędnicy państwowi - mają prawo do odmowy odpowiedzi na pytania.
} 
Taki stan rzeczy z oczywistych względów podważa zaufanie penitentów do szafarzy posługi religijnej a ich samych stawia w sytuacji konfliktu wartości i norm. Wszystko to godzi w istotę posługi, stanowiąc wyraźne pogwałcenie konstytucyjnie chronionej wolności sumienia i wyznania (religii) oraz prawa do dyskrecji związanego z życiem duchowym i praktykami religijnymi.

W świetle powyższego nasuwają się zatem dwa, zasadnicze postulaty de lege ferenda. Pierwszy to ten, iż należałoby pilnie wprowadzić do systemu prawa polskiego tajemnicę duszpasterską i obowiązek jej ochrony „zakotwiczyć” w ustawie. Wypełnienie tego postulatu mogłoby nastąpić poprzez wprowadzenie np. do ustawy z dnia 17 maja 1989 r. o gwarancjach wolności sumienia i wyznania ${ }^{36}$ definicji tajemnicy duszpasterskiej.

Postulat drugi: wprowadzając ustawowy obowiązek zachowania tajemnicy duszpasterskiej należałoby zaznaczyć, iż obowiązek zachowania tej tajemnicy ma pierwszeństwo przed obowiązkiem denucjacji.

Zatrzymując się przy tym postulacie i odnosząc się do przytoczonych wcześniej poglądów doktryny nie sposób nie zauważyć, iż obowiązek milczenia i obowiązek informowania nie idą z sobą w parze i nie mogą zachodzić równocześnie. Nie ulega przy tym wątpliwości, iż wolą ustawodawcy jest wyraźne podkreślenie szczególnej pozycji tajemnicy zawodowej w systemie prawa polskiego i zaznaczenie jej prymatu nad interesem wymiaru sprawiedliwości, o czym świadczy chociażby przyjęty przez ustawodawcę model ochrony tej tajemnicy, określony m.in. w art. $180 \$ 1$ i 2 k.p.k. ${ }^{37}$ Owa pozycja tajemnicy

\footnotetext{
${ }^{36}$ Dz.U. 1989, nr 29, poz. 155.

${ }^{37}$ Zgodnie $z$ art. $180 \$ 1$ k.p.k. osoby zobowiązane do zachowania tajemnicy związanej z wykonywaniem zawodu lub funkcji mogą odmówić zeznań co do okoliczności, na które rozciąga się ten obowiązek, chyba że sąd lub prokurator dla dobra wymiaru sprawiedliwości zwolni te osoby z obowiązku zachowania tajemnicy, jeżeli ustawy szczególne nie stanowią inaczej. W myśl natomiast art. $180 \$ 2$ k.p.k osoby obowiązane do zachowania tajemnicy adwokackiej (a także tajemnicy notarialnej, radcy prawnego, doradcy podatkowego, lekarskiej, dziennikarskiej lub statystycznej) mogą być przesłuchiwane co do faktów objętych tą tajemnicą tylko wtedy, gdy jest to niezbędne dla dobra wymiaru sprawiedliwości, a okoliczność
} 
zawodowej prowadzi zatem do wniosku, iż zawarty w art. $240 \$ 1$ k.k. obowiązek denucjacji co do zasady ustępuje przed obowiązkiem zawodowej dyskrecji wynikającym z ustawy. Tylko w taki sposób możliwa jest spójna i zgodna $\mathrm{z}$ wolą ustawodawcy ochrona tajemnicy zawodowej na gruncie procesu karnego, w tym również w odniesieniu do organów ścigania. Teza przeciwna, tj. ewentualne przyznanie obowiązkowi denuncjacji pierwszeństwa przed obowiązkiem dochowania zawodowej dyskrecji podważałoby sens istnienia wspomnianych mechanizmów chroniących tajemnicę zawodową przed dowodową penetracją i de facto czyniłby tę ochronę wysoce wątpliwą.

Wnioskowanie to zdaje się pośrednio znajdować oparcie także w poglądach Trybunału Konstytucyjnego, który wypowiadając się $\mathrm{w}$ przedmiocie reguł rządzących stosowaniem instytucji tajemnicy w wyroku m.in. z dnia 22 listopada 2004 r. stwierdził, iż „[... ], ustawodawca - raz decydując się na obciążenie określonej grupy zawodowej obowiązkiem zachowania tajemnicy - postępuje konsekwentnie, tj. w innych ustawach, wprowadzających obowiązek składania zeznań, przewiduje możliwość zachowania milczenia przez osoby związane tajemnicą. W przeciwnym razie, w pewnych sytuacjach wypełnienie obowiązku dyskrecji byłoby niemożliwe, a ochrona osób, w których interesie ten obowiązek wprowadzono, okazałaby się iluzoryczna"38.

W tym miejscu wyraźnie podkreślić trzeba, iż wprowadzenie ochrony tajemnicy duszpasterskiej nie ma na celu ochrony wybranej grupy osób (duchownych/zakonników). Jej ideą jest ochrona poufności tego, co w tajemnicy tej się mieści. Zarówno osoby zobowiązane do tajemnicy duszpasterskiej, jak i ich penitenci, winni mieć

nie może być ustalona na podstawie innego dowodu. Osobom obowiązanym do zachowania tajemnicy związanej z wykonywaniem zawodu ustawodawca przyznaje, w zakresie okoliczności, na które rozciąga się ten obowiązek, prawo odmowy zeznań, zaś pięć wskazanych w art. $180 \$ 2$ k.p.k. tajemnic zawodowych (adwokacką, notarialną, radcy prawnego, lekarską i dziennikarską) objął ochroną jeszcze silniejszą, a mianowicie zakazem przesłuchania niezależnym od woli świadka (zob. Z. Gostyński, Tajemnica dziennikarska a obowiązek składania zeznań w procesie karnym, Warszawa 1997, s. 113; P. Sowiński, Prawo..., dz. cyt., s. 156).

${ }^{38}$ SK 64/03, OTK 2004, Nr 10A, poz. 107. 
gwarantowane prawo do dyskrecji w zakresie wszelkich informacji związanych z posługą religijną. Nawet to, czego posługa dotyczyła i czy w ogóle miała miejsce, powinno być tą tajemnicą objęte. To bowiem, czy ktoś np. korzysta z pomocy kierownika duchowego, jest ochrzczony, czy ma ślub kościelny i czy przyjmuje wizytę duszpasterską, nie powinno być przedmiotem niczym nie skrępowanych procesowych analiz, gdyż dotyka intymnej sfery życia duchowego i uderza w prawo do prywatności praktyk religijnych.

Odnosząc się natomiast do zakresu podmiotowego analizowanej tajemnicy nie sposób nie zadać pytania, czy ma ona dotyczyć tylko osób duchownych. Jeśli weźmie się pod uwagę fakt, iż kierownikami (przewodnikami) duchowymi mogą być nie tylko osoby duchowne, ale również i „osoby zakonne” 39 , a nawet i świeckie, to czy depozytariuszami omawianej tajemnicy w znaczeniu wyżej wskazanym nie należałoby uczynić każdej z tych kategorii osób? Odpowiedź na to pytanie winna być - jak się wydaje - pozytywna w odniesieniu do osób zakonnych i negatywna w przypadku osób świeckich. Zweryfikowanie w praktyce „religijnego statusu” osoby świeckiej tzn. ustalenie czy jest ona kierownikiem duchowym czy nie, byłoby wysoce utrudnione i mogłoby stanowić pole do nadużyć, co nie oznacza jednakże, iż w przypadku istnienia tego rodzaju relacji, świecki kierownik duchowy w procesie karnym pozostawiony jest w sytuacji bez wyjścia. Zgodnie bowiem z art. 185 k.p.k. ${ }^{40}$, każda osoba może wnosić o zwolnienie ich od złożenia zeznań lub odpowiedzi na pytanie, jeżeli pozostaje z oskarżonym w szczególnie bliskim stosunku osobistym. Uwaga ta w jednakowym stopniu odnosi się również do osób zakonnych, jednakże w tym przypadku skala posług religijnych świadczonych przez osoby zakonne wydaje się być dużo większa a ich status zakonny - wykazujący wiele podobieństw do statusu osób

\footnotetext{
${ }^{39}$ Terminem tym posługuje się ustawodawca polski; osoby zakonne występują nie tylko w Kościele katolickim ale i w innych związkach wyznaniowych.

${ }^{40}$ Art. 185 k.p.k.: „Można zwolnić od złożenia zeznania lub odpowiedzi na pytania osobę pozostającą z oskarżonym w szczególnie bliskim stosunku osobistym, jeżeli osoba taka wnosi o zwolnienie".
} 
duchownych-jest stosunkowo prosty do zweryfikowania. Zakonnica będąca matką duchową kapłanów, lub okazjonalnie przeprowadzająca z nimi rozmowy duchowe, czy też wysłuchujący duchowych zwierzeń brat zakonny posługujący w noclegowni lub infirmerii nie powinni być obligowani do denuncjacji i należy to ustawowo zagwarantować.

Wracając do zasadniczego nurtu rozważań dotyczących drugiego ze zgłoszonych postulatów zauważyć trzeba, że podzielenie poglądu, iż ochrona tajemnicy zawodowej jest obowiązkiem co do zasady „silniejszym” niż obowiązek denucjacji rodzi pytanie, czy w takim razie w ogóle potrzebne jest wprowadzanie wyraźnego zapisu, iż w odniesieniu do tajemnicy duszpasterskiej regulacja art. 240 k.k. nie ma zastosowania?

Wydaje się, iż taki zapis nie byłby pozbawiony sensu, a to wobec - jak zasygnalizowano to wcześniej - wciąż trwającego sporu co do tego, czy tajemnica zawodowa ma charakter względny, czy też bezwzględny. Nie wchodząc w istotę dysputy ${ }^{41}$, jaka w tej materii toczy się od lat odnotować należy, iż gdyby rozpatrywać tajemnicę zawodową w kategoriach obowiązku względnego, to należy liczyć się z tym, że w takiej optyce możliwe jest wprowadzenie przepisu szczególnego, który obowiązek zachowania tajemnicy będzie modyfikował. Jak pokazuje dotychczasowe doświadczenie, np. zawarty w art. 40 ust. 2 ustawy z dnia 5 grudnia 1996 r. o zawodzie lekarza i lekarza dentysty ${ }^{42}$ zapis, zgodnie $z$ którym lekarz zwolniony jest $\mathrm{z}$ obowiązku zachowania tajemnicy m.in. wtedy, gdy tak stanowi ustawa, wciąż budzi polemiki co do swego zakresu znaczeniowego. Według np. M. Szewczyk, A. Wojtaszyka, W. Zontka, takie ogólne odesłanie do „innych ustaw” nie zwalnia z obowiązku zachowania

${ }^{41}$ Zob. Z. Skoczek, Spór o tajemnicę adwokacką, Palestra 1969, nr 2; E. Hansen, Tajemnica zawodowa adwokata, Palestra 1962, nr 9; tenże, Problem tajemnicy zawodowej, w: Socjologia zawodów, red. A. Sarapata, Warszawa 1965; B. KunickA-MichalsKa, Ochrona..., dz. cyt., s. 193; K. BuchaŁA, W sprawie sporu o tajemnice adwokacką, Palestra 1969, nr 2; M. Cieślak, S. Garlicki, A. Kaftal, Trójgłos w sprawie tajemnicy zawodowej adwokata, Palestra 1964, nr 3.

${ }^{42}$ Dz.U. z 2017 r. poz. 125 ze zm. 
tajemnicy zawodowej w perspektywie art. $240 \mathrm{k}$.k. gdyż przepis szczególny ${ }^{43}$ musi wskazywać, że podmioty zobowiązane do zachowania określonej tajemnicy są $\mathrm{z}$ niej zwolnione w zakresie, $\mathrm{w}$ jakim mają obowiązek przekazania informacji wskazanych w art. 240 k.k. ${ }^{44}$, natomiast L. Wilk ${ }^{45}$ prezentuje pogląd przeciwny.

Wprowadzenie zatem jednoznacznego zapisu, który wyraźnie określałby relację obowiązku dyskrecji w przypadku tajemnicy duszpasterskiej do obowiązku złożenia zawiadomienia o popełnieniu przestępstwa pozwoliłby uniknąć dylematów i wątpliwości jakie w omawianej materii mogą się pojawić.

Reasumując, należałoby postulować dokonanie nowelizacji wspomnianej ustawy o gwarancjach wolności sumienia i wyznania poprzez nadanie art. 12 następującej treści: „Art. 12 ust. 1. Duchowni oraz osoby zakonne kościołów i innych związków wyznaniowych, ustanowione według przepisów prawa wewnętrznego kościoła lub innego związku wyznaniowego, korzystają z praw i podlegają obowiązkom na równi z innymi obywatelami we wszystkich dziedzinach życia państwowego, politycznego, gospodarczego, społecznego i kulturalnego. Są oni w ramach obowiązujących przepisów ustaw zwolnieni z obowiązków niemożliwych do pogodzenia z pełnieniem funkcji duchownego lub osoby zakonnej. Osoby te zobowiazane sa do zachowania tajemnicy duszpasterskiej, która obejmuje wszelkie informacje uzyskane $w$ związku $z$ udzielaniem postugi religijnej. W odniesieniu do informacji objętych tajemnica duszpasterska art. 240 k.k. nie stosuje się".

Proponowane rozwiązanie zdaje się znajdować uzasadnienie w konstytucyjnej (art. 25 ust. 3) i konkordatowej (art. 1) zasadzie

\footnotetext{
${ }^{43}$ Autorzy ci wskazują, iż taki zapis zawarty został np. w art. 16 ustawy z dnia 26 stycznia 1984 r. - Prawo prasowe, Dz.U. poz. 24 ze zm., gdzie wyraźnie wskazano, że dziennikarz jest zwolniony z obowiązku zachowania tajemnicy zawodowej w zakresie informacji o przestępstwach ujętych w art. 254 k.k. z 1969 r. (odpowiednikiem tego przepisu jest obecnie art. 240 k.k.).

${ }^{44}$ Zob. M. Szewczy K, A. Wojtaszy , W. Zontek, dz. cyt., teza 10.

${ }^{45}$ L. Wilk, Obowiązek denuncjacji w prawie karnym (art.240 k.k.), Prokuratura i Prawo 1999, nr 1, s. 39.
} 
współdziałania państwa i kościoła dla dobra człowieka i dobra wspólnego. Nie wchodząc w szczegóły i różnice interpretacyjne ${ }^{46}$ dotyczące wskazanych pojęćc ${ }^{47}$ zauważyć jedynie należy, iż takie rozwiązanie nie tylko, jak wydaje się, w niczym nie narusza zasady autonomii obu wymienionych porządków prawnych ale wpisuje się w szerszy kontekst konstytucyjnych reguł dotyczących ograniczania praw jednostki w imię interesów natury ogólnej. Przepis art. 31 ust. 3 Konstytucji RP pozwala wszak ustawodawcy ograniczyć korzystanie z konstytucyjnych wolności i praw (a takimi są - jak wskazano wyżej - prawo do prywatności i wolności praktyk religijnych), tylko wtedy, gdy jest to konieczne dla bezpieczeństwa państwa, porządku publicznego, ochrony środowiska, zdrowia i moralności publicznej, albo wolności i praw innych osób.

W aktualnym stanie prawnym istnienie karnoprawnego obowiązku denuncjacji określonego w art. 240 k.k. przy jednoczesnym braku ochrony tajemnicy duszpasterskiej wskazuje, iż gwarancje wolności sumienia i wyznania (religii) oraz prawa do prywatności $\mathrm{w}$ aspekcie dotyczącym tajemnicy posługi duszpasterskiej nie tylko nie są respektowane w stopniu należytym, ale w zasadzie nie są respektowane wcale, co wymaga pilnej inicjatywy ustawodawczej.

\section{Denouncement Obligation Under Criminal Law (art. 240 of the Criminal Code) vs. the Privilege of Religious Service}

The amendment of art. 240 of the Criminal Code, effective as of 13 July 2017, has replaced the previous social obligation (art. 304 of the Code of Criminal Procedure) with the denouncement obligation under criminal law

${ }^{46}$ Szerzej zob. P. STeczkowski, Konstytucyjna zasada współdziałania państwa i kościoła, Studia z Prawa Wyznaniowego 11(2008), s. 155-170.

${ }^{47}$ Szerzej zob. J. KRUKOWSKI, Konstytucyjny model stosunków między państwem a kościołem w III Rzeczypospolitej, w: Prawo wyznaniowe w systemie prawa polskiego, red. A. Mezglewski, Lublin 2004, s. 98; A. Mezglewski, H. Misztal, P. StaNisz, Prawo wyznaniowe, Warszawa 2006, s. 78; W. GóRAlski, Wstęp do prawa wyznaniowego, Płock 2003, s. 101-102; M. Pietrzak, Prawo wyznaniowe, Warszawa 2003, s. 232. 
with reference to sex crimes. Expanding the substantive scope of the related obligation has been justified with the need to increase the protection of the victims of such crimes, especially minors and people who are inept due to their mental and physical condition.

Recognizing the abovementioned purpose of the amendment as necessary and socially important, it is worth asking the question about the relationship between the obligation under the analyzed legal norm and the freedom of conscience and religion, as guaranteed by the constitution as well as the right to privacy, including the right to discretion related to spiritual life and religious practice. Does the obligation to notify law enforcement authorities refer also to clergy and religious, who have obtained this kind of information while performing religious service? Does this obligation arise even when the victim expressly states during a spiritual conversation that they don't want the police or prosecutor to be informed and when there are reasons to suspect that a possible notification and its procedural consequences may have an adverse effect on the victim's psyche? The article will attempt to answer these questions.

SŁOWA KLUCZOWE: zawiadomienie o popełnieniu przestępstwa; denuncjacja; tajemnica duszpasterska; posługa religijna; seksualne wykorzystanie małoletniego

KEYWORDS: crime notification; denouncement; seal of the confession; religious service; sexual abuse of a minor

\section{Nota O AUTORACH:}

Ks. DR HAB. LUCJAn Świto, Prof. UWM - kierownik Katedry Prawa Kanonicznego i Filozofii na Wydziale Teologii Uniwersytetu Warmińsko-Mazurskiego w Olsztynie, oficjał Metropolitalnego Sądu Archidiecezji Warmińskiej.

Dr Makgorzata Tomkiewicz - wykładowca prawa na Wydziale Teologii Uniwersytetu Warmińsko-Mazurskiego w Olsztynie, sędzia Sądu Okręgowego w Olsztynie, przewodnicząca VII Wydziału Karnego Odwoławczego. 